PRESIDENT

Kendal Taylor CBE VICE PRESIDENTS

Fanny Waterman OBE

Peter Feuchtwanger

CHAIRMAN

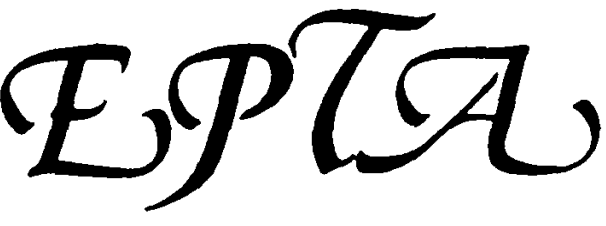

John Bigg

VICE CHAIRMEN

Harvey Dagul

Frank Martin

TREASURER

Alan Paul

Founder and Organising Secretary:

Carola Grindea

28 Emperor's Gate, London SW7 4HS

Tel: 071-373 7307

Administrator: Josephine Richardson

EPTA - European Piano Teachers Association - is now a well established organisation with 20 national associations:

EPTA UK, EPTA ICELAND, EPTA WEST

GERMANY, EPTA BELGIUM, EPTA HOLLAND, EPTA FINLAND, EPTA FRANCE, EPTA EIRE, EPTA SWITZERLAND, EPTA AUSTRIA, EPTA NORWAY, EPTA YUGOSLAVIA, EPTA SWEDEN, EPTA

CZECHOSLOVAKIA, EPTA USSR, EPTA ITALY, EPTA EAST GERMANY, EPTA HUNGARY, EPTA ROMANIA AND EPTA MALTA.

EPTA publishes the Piano Journal - the only European magazine devoted entirely to the piano - which is free to EPTA UK members and Associate members (those living in countries where there are no EPTA Associations).

Piano Journal is available for non-members by subscription at $£ 6.00$ or US $\$ 12.00$ (including postage)

UK Annual Membership

$£ 15.00$ (fifteen pounds) per annum

$£ 20.00$ (twenty pounds) for husband and wife $£ 5.00$ (five pounds) for students

Associate Members: $£ 10.00$ (US $\$ 15.00$ ) 


\title{
The Quarterly
}

\section{Expanding the Frontiers of Knowledge in Music Learning and Teaching}

\author{
Manny Brand, Editor
}

The Quarterly publishes original manuscripts of interest to all who are involved with the learning and teaching of music. Forthcoming themed issues include:

- International Music Education. Music educators from around the globe write about the circumstances, goals, and structures of the field in their countries.

- The Work of Edwin E. Gordon. This brilliant and controversial body of work is examined from a number of perspectives in this issue.

- Reviews of A Pbilosophy of Music Education (2nd ed.) by Dr. Belinett Reimer. Reviews by noted music philosophers and responses by Dr. Reimer are the focus of this issue.

Manuscripts are now being invited for review and possible publication in these forthcoming issues:

- Music Learning and Teaching in the Applied Studio Deadline: July15

- Music Education Research--Reconsidered Deadline: August 15

What is the worth of experimental research? What is the worth of philosophical, historical, and qualitative research in music education? Research as a means of ascent in the professoriate.

- Music Education in the Soviet Union Deadline: September 15

Authors are also encouraged to submit manusctripts that deal with other aspects of music education inquiry, for manuscripts on all appropriate topics are reviewed continuously by The Quarterly's editors.

For a sample copy of The Quarterly, subscription information, and Guidelines to Contributors, contact Doree N. Pitkin, Managing Editor, University of Northern Colorado School of Music, 123 Frasier Hall, Greeley, CO 80639. 


\title{
BRITISH JOURNAL OF MUSIC EDUCATION
}

\author{
Editors \\ PROFESSOR JOHN PAYNTER Department of Music, University of York, Heslington, York YOI SDD
}

PROFESSOR KEITH SWANWICK Department of Music, University of London Institute of Education, 20 Bedford Way, London $W C_{I} H o A L$

\section{Review Editor \\ ANDREW PEGGIE 4 Colchester Avenue, Manor Park, London E $125 L E$}

Editorial Board

JOANNA GLOVER

Bath College of Higher Education

MARJORIE GLYNNE-JONES

Towver Hamlets Inspectorate

ANTHONY KEMP

Music Education Centre, University of Reading

BRIAN LOANE

Sunderland Polytechnic

KEITH SEDGEBEER

Wolverhampton LEA

JAMES SLOGGIE

Edinburgh

DOROTHY TIPTON

Christ Church College, Canterbury

\author{
International Advisory Board \\ GRAZIELA CINTRA GOMES \\ Portuguese Assoc. of Musical Education \\ WILLI GUNDLACH \\ University of Dortmund, Germany \\ DAVID SMITH \\ Kingston, Ontario, Canada \\ EINAR SOLBU \\ Norwegian State Academy of Music \\ ELLEN URHO \\ Sibelius Academy, Finland \\ DAVID WALKER \\ The Aaron Copland School of Music, CUNY \\ YU WAKAO \\ Hiroshima University \\ ANDRZEJ WILK \\ Music Academy, Cracow
}

The British Journal of Music Education is now established in the field as a key publication, nationally and internationally. The aims of the BJME are to provide clear, stimulating and readable accounts of curriculum development and research in music education. Editorial policy is to encourage careful reflection on teaching in schools, colleges and studios.

Articles are invited from those in any way concerned with music education, and, where appropriate, can be of substantial length, though shorter contributions are also acceptable. Potential authors are referred to the notes for contributors (see inside back cover).

Usually once a year a cassette of music examples accompanies the Journal and contributors may wish to take advantage of this. Photographs and other illustrations are welcomed.

\section{(C) Cambridge University Press I99I}

Copying: This journal is registered with the Copyright Clearance Center, 27 Congress St., Salem, Mass. or970. Organizations in the USA who are also registered with C.C.C. may therefore copy material (beyond the limits permitted by sections 107 and 108 of US copyright law) subject to payment to C.C.C. of the per copy fee of $\$ 5.00$. This consent does not extend to multiple copying for promotional or commercial purposes. Code 0265-0517/90 $\$ 5.00+.00$.

ISI Tear Sheet Service, 350I Market Street, Philadelphia, Pennsylvania 19104, USA, is authorised to supply single copies of separate articles for private use only.

For all other use, permission should be sought from Cambridge or the American branch of Cambridge University Press.

Subscriptions: British fournal of Music Education (ISSN 0265-0517) is published in volumes of three parts in March, July and November. The subscription price (which includes postage) of volume 8, 1991 is $£ 33.00$ in UK $£ 36$ elsewhere, (US $\$ 55.00$ in USA and Canada) for institutions, $£ 21.00$ (US $\$ 35.00$ in USA and Canada) for individuals ordering direct from the Press and certifying that the journal is for their personal use. $£ 16.00$ (US $\$ 27.00$ in USA and Canada) for students. Single parts cost $£ 12.00$ net (US $\$ 20.00$ in USA and Canada) plus postage. Orders, which must be accompanied by payment, may be sent to a bookseller, subscription agent or direct to the publishers: Cambridge University Press, The Edinburgh Building, Shaftesbury Road, Cambridge $\mathrm{CB}_{2} 2 \mathrm{RU}$. Orders from the USA or Canada should be sent to Cambridge University Press, The Journals Department, 40 West 20th Street, New York, NY IO0I I-42 I I, USA. Second class postage paid at New York, NY, and at additional mailing offices. POSTMASTER: send address changes in USA and Canada to British fournal of Music Education, Cambridge University Press, I Io Midland Avenue, Port Chester, New York, NY I0573-9864. Copies of the journal for subscribers in the USA and Canada are sent by air to New York to arrive with minimum delay. 


\section{BRITISH \\ JOURNAL OF \\ MUSIC \\ EDUCATION}

VOLUME 8

1991

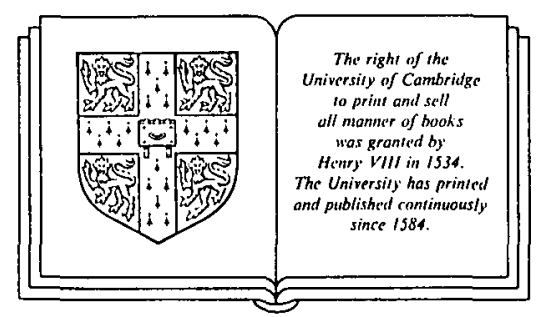

CAMBRIDGE UNIVERSITY PRESS

Cambridge

New York Port Chester Melbourne Sydney 
Published by the Press Syndicate of the University of Cambridge The Pitt Building, Trumpington Street, Cambridge CB2 1RP 40 West 20th Street, New York, NY 10011-4211, USA 10 Stamford Road, Oakleigh, Victoria 3166, Australia

(C) Cambridge University Press 1991

Printed in Great Britain by the University Press, Cambridge 


\title{
CONTENTS TO VOLUME 8
}

\author{
TABLE OF CONTENTS \\ BRITISH JOURNAL OF MUSIC EDUCATION
}

Vol. 81991

(Book reviews in italic letters)

NUMBER I, MARCH I99I

Biographical Notes on Contributors

John Bence: GCSE and Early Music

Clayton G. MacKenzie: Starting to Learn to Play a Musical Instrument: a Study of Boys' and Girls' Motivational Criteria

Simon Cargill and George Pratt: Up and Running: An Update on the RAMP Unit's Work at Huddersfield Polytechnic

Michael J. A. Howe and John A. Sloboda: Young Musicians'

Accounts of Significant Influences in their Early Lives. 1. The

Family and the Musical Background

Michael J. A. Howe and John A. Sloboda: Young Musicians'

Accounts of Significant Influences in their Early Lives. 2.

Teachers, Practising and Peforming

Peter Dunbar-Hall: Music and Language: Commonalities in Semiotics, Syllabus, and Classroom Teaching

A reply by Cecilia Vajda to the article by Bernarr Rainbow, The Kodály Concept and its Pedigree, BJME, Vol. 7 No. 3

Information

Aural Awareness: Principals and Practice by George Pratt, with Michael Henson and Simon Cargill

The Tower Hamlets String Teaching Project: Research Report by Keith Swanwick and Christine Jarvis

Studying Popular Music by Richard Middleton

Creative Improvisation by Roger Dean

Composing in the Classroom by Ruth Harris and Elizabeth Hawksley

GCSE Music Skills - Composing by Martin Hinckley

Composing at the Electronic Keyboard by Nicholas Haines

Music All the Time (books 2 and 3) by Wendy Bird and Elizabeth Bennett

Pitch in 2 by fean Maughan

Story, Song and Dance by fean Gilbert $\quad 93$

Music Through Topics : an activity resource by Veronica Clark 93

Read Rhythm Right by Claire Lester 
Musical Terms, Symbols and Theory: an illustrated dictionary by

Michael Thomsett

Trackings. Composers speak with Richard Dufallo

NUMBER 2, JULY I99I

Biographical Notes on Contributors

Jonathan Stock: A Case for World Music

Robert Kwami: An Approach to the Use of West African Musics in the Classroom, Based on Age and Gender Classifications

Keith Swanwick: Musical Criticism and Musical Development

Nita Temmerman: The Philosophical Foundations of Music

Education: The Case of Primary Music Education in Australia

Peter Auker: Pupil Talk, Musical Learning and Creativity

Martin Gellrich : Concentration and Tension

Information

Letters

Ear Training for Twentieth Century Music by Michael L. Friedmann

The Claims of Feeling : Readings in aesthetic education edited by Malcolm Ross

Creative Jazz Education by Richard Michael and Scott Stroman

Indian Music in Education by Gerry Farrell

Guitar Technique - Intermediate to Advanced by Hector Quine

Guidelines to Piano Interpretation by Siglind Bruhn

British Music Yearbook 1991 edited by Annabel Carter

British Music Education Yearbook 1990/91 edited by Annabel Carter

Recent music for woodwind surveyed

'And Do You Also Play the Violin?' by Carl F. Flesch

The Liveliest Way to Take up fazz by Art Marshall

The Study of Fugue by Alfred Mann

Making the Grade: how to pass your music exam by Paul Harris

\section{NUMBER 3, NOVEMBER I99I}

Biographical Notes on Contributors

Prefactory Note

Richard Addison: Music and Play 
Marion Rooke: Constructive Creations

John P. Verney: The Integrated Instrumental Teacher: Learning to Play Through Performance, Listening and Composition

Janet Nicolls: Freedom and Structure: The Acquisition of Language in a Musical Education

Notes on the Contents of the Cassette Tape

Music in Educational Thought and Practice: a survey from $800 B C$ by Bernarr Rainbow

The New Composer by William Salaman

Learning to Compose by fohn Howard

High Low Dolly Pepper by Veronica Clark

Start the Electronic Keyboard, books 1 and 2 by Nick Haines

Sounds Around, books 1 and 2 by Cliff Matthews

Contemporary Percussion by Reginald Smith Brindle

The Oxford Companion to Popular Music by Peter Gammond

Recent songbooks for classroom and assembly surveyed

Recent songbooks for funiors surveyed

Books Received 


\section{NOTES FOR CONTRIBUTORS}

The prime aims of the Journal are that articles should be of interest to teachers of music and show evidence of careful and critical enquiry.

Contributions and correspondence should be sent to one of the Editors:

$\begin{array}{lll}\text { either } & \text { Professor John Paynter } & \text { Professor Keith Swanwick } \\ \text { Department of Music } & \text { or } & \text { Department of Music } \\ \text { University of York } & & \text { University of London } \\ \text { Heslington } & \text { Institute of Education } \\ \text { YORK YOI 5DD } & \text { Bedford Way } \\ & & \text { LONDON wCIH OAL }\end{array}$

Material for review and review copy should be sent to the Review Editor:

Andrew Peggie, 4 Colchester Avenue, Manor Park, London, E1 2 SLE

\begin{tabular}{|c|c|c|}
\hline SUBMITTED & Length & normally between 2,000 and 10,000 words. \\
\hline $\begin{array}{l}\text { ARTICLES AND } \\
\text { REVIEWS }\end{array}$ & Format & typed in double-spacing on $A 4$ or equivalent, one side only, with \\
\hline
\end{tabular}

Abstract about 100 words; summarizing the contents of the article; should be typed immediately below the title and author's name and above the main text. A note giving details of any acknowledgements should also be included.

Biographical of c. 75 words giving affiliation, principal publications, etc. should be note submitted on a separate sheet.

Copies 3 copies of articles and one of reviews should be submitted and one retained for proof-reading.

Language writing should be clear, and jargon free; subheadings are helpful in long articles.

Stereotyping all forms of racial and gender stereotyping should be avoided.

It is hoped that writers will take the opportunity to present musical examples on tape. Usually a cassette tape is produced once a year, normally following the third issue of the Journal. It will have a maximum duration of ninety-two minutes and may refer to articles in each of the issues.

$\begin{array}{ll}\text { SUBMITTED } & \begin{array}{l}\text { Type } \\ \text { Quality } \\ \text { Content } \\ \text { Examples }\end{array} \\ & \\ \begin{array}{l}\text { ACCEPTED } \\ \text { ARTICLES } \\ \text { AND REVIEWS }\end{array} & \text { Proofs } \\ \end{array}$

cassette or open-reel.

the highest possible to facilitate transfer.

in final edited form.

should not be numbered on the tape; a written numbered list of items, with timings, should be provided.

writers have the opportunity, with a given deadline, of correcting essential factual errors and any printer's errors.

AND REVIEWS Copyright

writers are responsible for obtaining necessary permissions to quote copyright material; writers will be requested to assign their copyright to Cambridge University Press.

Offprints 25 free offprints are supplied to writers of published articles, these shared between joint authors; further offprints may be purchased if ordered at proof stage. 


\section{QUOTATIONS AND REFERENCES}

Please identify these in the text by author and by date in brackets, e.g. '(Holmes, I98r)', and list all references alphabetically by surname on a separate sheet at the end:

\section{format}

type in doublespacing on $\mathrm{A}_{4}$ or equivalent

\author{
for books state \\ surname, initials \\ publication date \\ (in brackets) \\ title (underlined) \\ place of \\ publication \\ publisher
}

\author{
for articles state \\ surname, initials \\ publication date \\ (in brackets) \\ full title (not \\ underlined) \\ journal title \\ (underlined) \\ volume number \\ issue number \\ page number(s)
}

$\begin{gathered}\text { for articles in } \\ \text { books state }\end{gathered}$
author's name
publication date
(in brackets)
title (in quotes)
'in'
editor's name
book title
(underlined)
place of
publication
publisher
other notes only if essential
number consecutively number in superscript list on separate sheet at end

\footnotetext{
Please note: 'Eds' without point

' $\&$ ' for joint authors and in publishers' names
}

FOR EXAMPLE Alvin, J. (I975) Music Thearapy. London: John Clare.

Boyd Willard L. (1984) 'Music: basic education'. In Donald A. Shetler (Ed), The Future of Musical Education in America, vol. 3. pp. 321-7. Rochester, NY: Eastman School of Music Press.

Holmes. M. (1981) The secondary school in contemporary western society: constraints, imperatives, and prospects. Curriculum Inquiry, 15, I, 7-36.

Howe, I. (1985) 'A plea for pluralism'. In Beatrice \& Ronald Gross (Eds), The Great School Debate, pp. 361-2. New York: Simon \& Schuster.

Scherer, K. R. \& Ekman, P. (Eds) (1984) Approaches to Emotion. Hillsdale, NJ: Erlbaum \& Associates.

\section{ILLUSTRATIONS}

\section{captions}

list and number consecutively on a separate sheet

\section{photographs}

use well-contrasted black and white prints, preferably portrait style no smaller than text width (143 mm) with glossy finish; lightly put writer's name and figure number on the back in pencil

\section{drawings and diagrams}

use Indian ink and strong paper, white card, or good quality tracing paper 


\section{BRITISH JOURNAL OF MUSIC EDUCATION}

\section{Volume 8 Number 3, November 1991}

\section{CONTENTS}

Biographical Notes on Contributors $\quad 203$

$\begin{array}{ll}\text { Prefatory Note } & 205\end{array}$

$\begin{array}{ll}\text { Richard Addison: Music and Play } & 207\end{array}$

$\begin{array}{ll}\text { Marion Rooke: Constructive Creations } & 219\end{array}$

John P. Verney: The Integrated Instrumental Teacher: Learning to Play Through Performance, Listening and Composition

Janet Nicolls: Freedom and Structure: The Acquisition of Language in a Musical Education

Notes on the Contents of the Cassette Tape

\section{BOOK REVIEWS}

c Cambridge University Press I99I

Cambridge University Press

The Pitt Building, Trumpington Street, Cambridge CB2 IRP

40 West 20th Street, New York, NY 100I1-421 I, USA

Io Stamford Road, Oakleigh, Victoria 3166, Australia

Printed in Great Britain by the University Press, Cambridge 